\title{
COMPARISON OF THE MANGROVE SOIL WITH DIFFERENT LEVELS OF DISTURBANCE IN TROPICAL AGUA BRAVA LAGOON, MEXICAN PACIFIC
}

\author{
GUTIÉRREZ, J. C. S. ${ }^{1}$ - PONCE-PALAFOX, J. T. ${ }^{2 *}$-PINEDA-JAIMES, N. B. ${ }^{1}$ - ARENAS- \\ FUENTES, $\mathrm{V}^{3}{ }^{3}$ - ARREDONDO-FIGUEROA, J. L. ${ }^{4}-$ CIFUENTES-LEMUS, J. L. ${ }^{5}$ \\ ${ }^{I}$ Posgrado en Ciencias Ambientales. Facultad de Geografía. Universidad Autónoma del Estado \\ de México. Edo. de México C.P. 50000 \\ ${ }^{1,2}$ Lab. de Bioingeniería Costera. Escuela Nacional de Ingeniería Pesquera. Unidad \\ Multidisciplinaria de Bahía de Banderas. Universidad Autónoma de Nayarit. Nayarit, México. \\ C.P. 63155
}

${ }^{3}$ Instituto de Ciencias Marinas y Pesquerías, Universidad Veracruzana. Boca del Río, Veracruz, México. C.P.94290

${ }^{4}$ Centro de Ciencias Agropecuarias. Universidad Autónoma de Aguascalientes, Jesús María. Aguascalientes. México. C.P. 2013

${ }^{5}$ Centro Universitario de La Costa. Universidad de Guadalajara, Pto. Vallarta, Jal. México. C.P. 48280.

*Corresponding author

e-mail: jesus.ponce@usa.net; tel: 052+311-2118800

(Received 29 $9^{\text {th }}$ Mar 2016; accepted $20^{\text {th }}$ Jun 2016)

\begin{abstract}
The texture and geochemical parameters of soil in tropical mangrove ecosystems have been broadly studied, but the effect of environmental stress on mangrove soil with different levels of disturbance has not been established. This study aimed to compare the texture and soil geochemistry of mangrove ecosystems with two levels of disturbance in the tidal basin of Agua Brava Lagoon, National Wetlands Nayarit, Mexico. Forty eight soil samples were collected from two areas of the mangrove ecosystem during an annual cycle; one in high mangrove condition (according to estimated Leaf Area Index) with low disturbance (LD) and the other in poor mangrove condition with high disturbance (HD). Generally, soil texture tends to be softer in LD than HD sites. LD sites had higher concentration of total N and $\mathrm{P}$, organic matter $(\mathrm{OM})$ and organic carbon $(\mathrm{OC})$. HD sites presented an environmental stress with high levels of $\mathrm{Ca}, \mathrm{Na}$, salinity and conductivity. We identified four processes that dominate the dynamics of soil in the study area; MO, OC, N relationship and acid-base relationship. In conclusion, the soil conditions of LD and HD sites are dissimilar according to the level of mangrove disturbance, thus demonstrating the importance to maintain healthy mangrove ecosystem.
\end{abstract}

Keywords: cation exchange capacity, nutrient, organic matter, texture

\section{Introduction}

The tropical coastal wetlands have been considered a key ecosystem because they have complex physical, chemical, biological and ecological relationships. Furthermore, they turnover, transform and export particulate and dissolved organic and inorganic nutrients of terrestrial origin (Molnar et al., 2013), trap and stabilize sediments (Nerot et al., 2009). The annual cycle of inundation of coastal lagoons with cracking sediments is very relevant for the local biogeochemistry of organic matter and phosphorus (Arenas and De la Lanza, 1981). The processes occurring in the mangrove forests and salt 
marshes soil are mainly affected by type of clays, organic matter, grain size, cation exchange capacity and mineral constituents (Vertacnik et al., 1995), as well as the activities of fauna and flora. All these factors contribute to determining the biogeochemical conditions of the soil (Chen and Ye, 2010). A number of geochemical parameters of soil in the subtropical mangrove forests and salt marshes along transects running landward to seaward have been studied; among those found are changes in soil particle size distribution (Lyu et al., 2015), texture and geochemistry of the sediments (Madkour et al. 2014), heavy metal (Tam and Wong, 2000; Otero et al., 2009; Sun et al., 2015), distribution of phosphorus and nitrogen (Ramos e Silva et al., 2007; Ranjan et al., 2011; Zhang et al., 2014; Ramírez-Fuentes et al., 2015), variations in nutrient and organic matter (Marchand et al., 2004; Aschenbroich et al., 2015), characteristics and vegetation structure (Cardona and Botero, 1998), gradients in salinity and nutrient resources (Chen and Twilley, 1999) and temporal variability of $\mathrm{CO}_{2}$ fluxes at the sediment-air interface (Leopold et al., 2015).

\section{Review of Literature}

The mangrove forests and salt marshes control the tidal wetland ecosystem dynamics and contribute to the development and condition of the tidal saline wetland ecological communities (Alongi, 2009). Mangrove forests and salt marshes are highly valued ecosystems; however, mangrove forests and salt marshes maintain divergent ecological communities and a different suite of goods and services (Barbier et al., 2011). Climate change, environmental stress and anthropogenic activities can cause the conversion of mangrove forest to salt marshes, with positive and negative expected and unexpected consequences (e.g., effects upon fish and wildlife populations, ecosystem resilience, nutrient cycling, and variation of texture and soil geochemistry). The physicochemical conditions and ecological implications of these mangrove forests to salt marshes conversions are poorly understood, but would likely include changes in soil, water, associated wildlife populations and supply of some ecosystem goods and services (Osland et al., 2013). However, few studies have shown soil characteristics of areas with different levels of disturbance in mangrove forests, salt marshes and estuaries. Although there have been a number of studies in mangrove ecosystems and salt marshes soil in other countries (Chen and Ye, 2010; Polania et al., 2015), few data are available in the tropical and subtropical regions; particularly in the northwestern Mexico (Arenas and De la Lanza, 1983; Kovacs, 2000; Kovacs et al., 2005; Hernández-Guzmán et al., 2008; Kovacs et al., 2009; Zhang et al., 2014). That region is one of the largest mangrove forests on the western coast of the Americas (Fig. 1). The coastal study site ecosystem subject to considerable degradation caused by hydrologic changes, changes in salinity and tidal regime have adversely impacted over mangrove and salt marshes following the opening of a channel (Channel Cuautla) in 1976 aimed for increasing fish productivity (Flores-Verdugo et al., 2014). This has caused a significant disturbance to the mangrove ecosystem, salt marshes and estuaries, primarily due to environmental stress (Kovacs et al., 2009) which resulted to increased salinity in the system because of the increased input from sea water which has caused mass mortalities of the white mangrove primarily for being sensitive to increases in salinity (Pool et al., 1977; FloresVerdugo et al., 2014). The aim of this study was to compare the texture and soil geochemistry of the mangrove ecosystem with different levels of disturbance in the tidal basin of Agua Brava Lagoon in National Wetlands Nayarit, Mexico. 


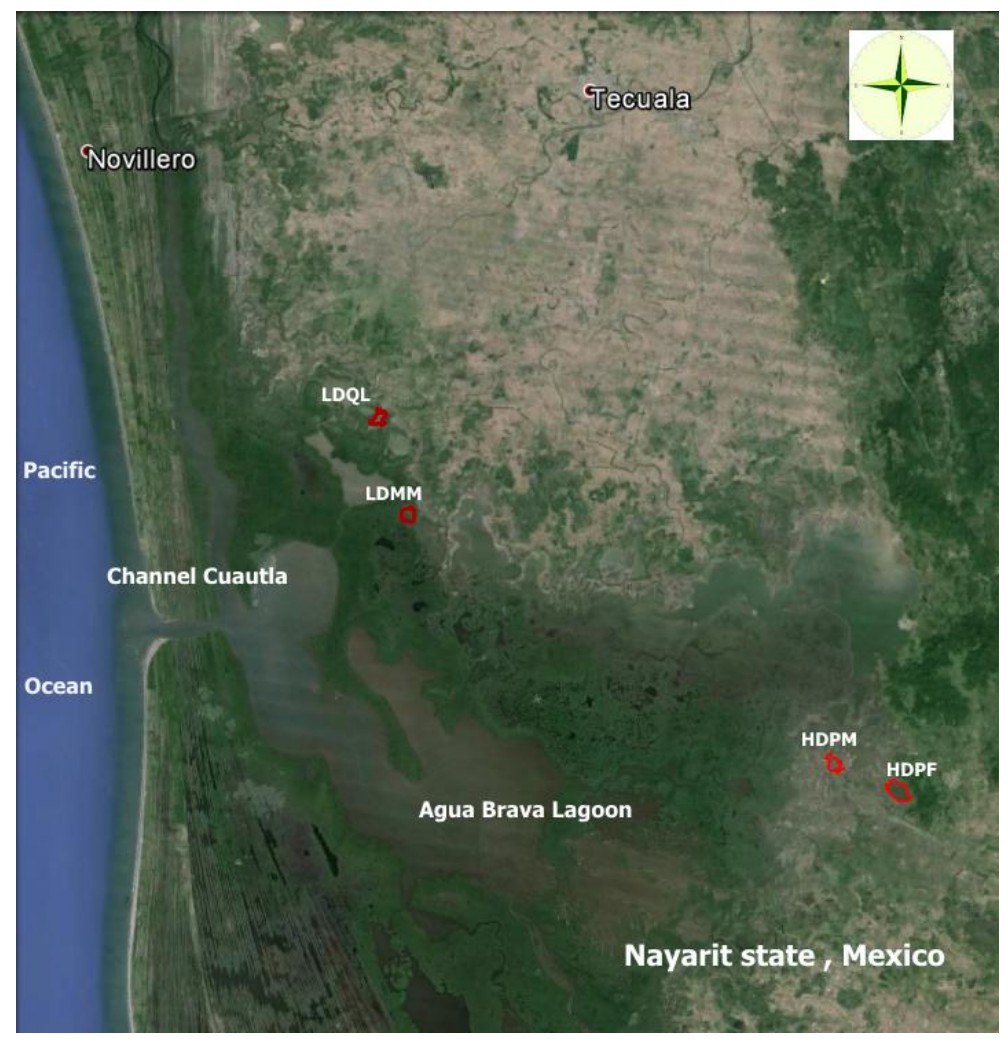

Figure 1. Location of study area Agua Brava Lagoon in National Wetlands Nayarit, Mexico. Sampling stations: $L D Q L=$ Lagoon Lacustrine Delta Quimichis; $L D M M=$ Mangrove Lacustrine Delta Murillos; HDPF = Floodplains Pericos1 Lacustrine Delta San MiguelitoPericos1; HDPM = Mangrove Lacustrine Delta San Miguelito-Pericos2.

\section{Materials and Methods}

Surface duplicate samples (approximately $1 \mathrm{~kg}$ ) of soil (0-10 $\mathrm{cm}$ deep) were collected monthly from two sites with high mangrove condition based on an estimated leaf area index mapping approach (Kovacs et al., 2005), with low disturbance (LD) in the lagoon lacustrine delta of Quimichis (LDQL; 22 $16^{\prime} 02.89^{\prime \prime} \mathrm{N} ; 105^{\circ} 32^{\prime} 54.23^{\prime \prime} \mathrm{W}$ ) and mangrove lacustrine delta of Murillos (LDMM; 22 $\left.2^{\circ} 13^{\prime} 41.61^{\prime \prime} \mathrm{N} ; 105^{\circ} 32^{\prime} 11.39^{\prime \prime} \mathrm{W}\right)$; an area in which there are riverine mangroves in tidal channels and lagoons surrounding, and two sites with poor mangrove condition with high disturbance (HD); one in the flood plains lacustrine delta of San Miguelito-Pericos (HDPF; 22 $07^{\prime} 19.71^{\prime \prime N}$; 105 $19^{\prime} 42.62^{\prime \prime} \mathrm{W}$ ) and mangrove lacustrine delta of San Miguelito-Pericos (HDPM; 22 $07^{\prime} 58.07^{\prime \prime N}$;105'21'22.04'W), where there are basin, dwarf mangrove and seasonal flood plains during annual cycle (July 2014 to June 2015) using sediment samplers-Van Veen grabs. The soil was placed into plastic bags and brought to the laboratory for posterior analysis. In the laboratory, the soil samples were freeze-dried, slightly crushed, passed through $2 \mathrm{~mm}$ sieve, and stored in glass bottles for their respective analysis.

The sand, silt and clay content of the samples were determined by modification of the Bouyoucos method (Beretta et al., 2014). The field moisture content was obtained by subtracting oven-dry weight from wet weight of the field samples. The soil $\mathrm{pH}$ was measured in 1:2 soil : water suspension using a glass electrode; electrical conductivity (EC) was measured in 1:1 soil : water suspension using a glass electrode; Sediment bulk density (D) was obtained from the wet weight of a known sediment volume; 
organic carbon (OC) was obtained by the Walkley-Black method and residual organic phosphorus available $(\mathrm{P})$ was measured after $1 \mathrm{~h} \mathrm{~K} \mathrm{~K}_{2} \mathrm{~S}_{2} \mathrm{O}_{8}$ digestion in an acidic medium (Joseph et al., 2011). Cations were extracted in ammonium acetate (pH 7) and evaluated by calcium $(\mathrm{Ca})$, magnesium $(\mathrm{Mg})$, potassium $(\mathrm{K})$ and sodium $(\mathrm{Na})$. Atomic absorption by flame photometry (Hendershot et al., 2008) and organic matter was determined by loss on ignition $\left(550^{\circ} \mathrm{C}, 4 \mathrm{~h}\right.$; Parker, 1983).

Prior to statistical analysis, sand, silt, clay, OM and OC data were arccosine $(x+0.01)$ transformed, and nitrogen, $\mathrm{P}, \mathrm{K}, \mathrm{Ca}, \mathrm{Mg}$ and $\mathrm{EC}$ were $\log (\mathrm{x}+1)$ transformed and all the data were tested for homoscedasticity (Bartlett test) and normal distribution (ShapiroWilk). Differences in concentrations or percent of texture and soil chemical characteristics parameters were tested using analysis of variance (ANOVA). Tukey's HSD post-hoc test was then used to determine the differences between groups. Pearson correlation coefficient matrix was constructed with each of the variables.

Homogeneous groups of station and their temporal variations were displayed by Cluster analysis (CA) applied to a Pearson correlation coefficient matrix and all variables were applied principal component analysis (PCA), using Minitab ${ }^{\circledR}$ 15.1.30.0.

\section{Results}

Sand and $\mathrm{pH}$ were similar in all sites (Table 1). A higher concentration $(\mathrm{p}<0.05)$ of clay, density, OM, OC, $\mathrm{N}$ and $\mathrm{K}$ were found in LD sites, and higher concentration $(\mathrm{p}<0.05)$ of $\mathrm{Ca}, \mathrm{Na}$, conductivity and salinity were found in $\mathrm{HD}$ sites. The $\mathrm{P}$ and $\mathrm{Mg}$ concentrations were higher in mangrove forest sites. The $\mathrm{C} / \mathrm{P}$ proportion had a tendency to be higher in lagoon and flood plains than in mangrove forest.

Table 1. Texture and soil chemical parameters of the tropical tidal basin Agua Brava Lagoon. *LDQL = Lagoon Lacustrine Delta Quimichis; LDMM = Mangrove Lacustrine Delta Murillos; HDPF = Floodplains Lacustrine Delta San Miguelito-Pericos $1 ; H D P M=$ Mangrove Lacustrine Delta San Miguelito-Pericos2.

\begin{tabular}{lcccc}
\hline Parameter & LDQL $^{*}$ & LDMM & HDPF & HDPM \\
\hline Sand (\%) & $32.67 \pm 5.70^{\mathrm{a}}$ & $30.75 \pm 4.52^{\mathrm{a}}$ & $34.51 \pm 4.35^{\mathrm{a}}$ & $36.15 \pm 4.29^{\mathrm{a}}$ \\
Silt $(\%)$ & $32.70 \pm 3.52^{\mathrm{b}}$ & $40.26 \pm 5.32^{\mathrm{a}}$ & $44.03 \pm 5.16^{\mathrm{a}}$ & $34.78 \pm 3.82^{\mathrm{b}}$ \\
Clay (\%) & $33.44 \pm 3.72^{\mathrm{a}}$ & $27.52 \pm 3.24^{\mathrm{a}, \mathrm{b}}$ & $21.14 \pm 3.65^{\mathrm{b}}$ & $25.95 \pm 2.19^{\mathrm{b}}$ \\
Density $\left.(\mathrm{g} \mathrm{mL})^{-1}\right)$ & $1.22 \pm 0.44^{\mathrm{a}}$ & $1.15 \pm 0.40^{\mathrm{a}}$ & $0.87 \pm 0.02^{\mathrm{b}}$ & $0.87 \pm 0.03^{\mathrm{b}}$ \\
Texture & clay loam & clay loam & silty loam & clay loam \\
Organic matter (\%) & $4.55 \pm 0.72^{\mathrm{a}}$ & $4.83 \pm 0.59^{\mathrm{a}}$ & $2.79 \pm 0.29^{\mathrm{b}}$ & $3.20 \pm 1.54^{\mathrm{b}}$ \\
Organic Carbon (\%) & $2.69 \pm 0.41^{\mathrm{a}}$ & $2.79 \pm 0.34^{\mathrm{a}}$ & $1.72 \pm 0.17^{\mathrm{b}}$ & $1.45 \pm 0.89^{\mathrm{b}}$ \\
Nitrogen $(\mathrm{g} / \mathrm{kg})$ & $0.14 \pm 0.04^{\mathrm{a}}$ & $0.14 \pm 0.05^{\mathrm{a}}$ & $0.08 \pm 0.06^{\mathrm{b}}$ & $0.09 \pm 0.05^{\mathrm{b}}$ \\
P (g/kg) & $0.012 \pm 0.008^{\mathrm{b}}$ & $0.020 \pm 0.005^{\mathrm{a}}$ & $0.013 \pm 0.003^{\mathrm{b}}$ & $0.024 \pm 0.005^{\mathrm{a}}$ \\
C/N & 19.21 & 19.93 & 21.50 & 16.11 \\
C/P & $227.97^{\mathrm{a}}$ & $138.81^{\mathrm{b}}$ & $131.30^{\mathrm{b}}$ & $60.67^{\mathrm{c}}$ \\
Potassium $(\mathrm{g} / \mathrm{kg})$ & $1.81 \pm 0.26^{\mathrm{a}}$ & $1.87 \pm 0.26^{\mathrm{a}}$ & $1.64 \pm 0.11^{\mathrm{b}}$ & $1.73 \pm 0.13^{\mathrm{b}}$ \\
Calcium $(\mathrm{g} / \mathrm{kg})$ & $2.84 \pm 0.41^{\mathrm{b}}$ & $1.98 \pm 0.29^{\mathrm{b}}$ & $3.09 \pm 0.34^{\mathrm{a}}$ & $3.45 \pm 0.38^{\mathrm{a}}$ \\
Magnesium $(\mathrm{g} / \mathrm{kg})$ & $0.85 \pm 0.17^{\mathrm{b}}$ & $1.90 \pm 0.59^{\mathrm{a}}$ & $1.32 \pm 0.14^{\mathrm{b}}$ & $1.81 \pm 0.44^{\mathrm{a}}$
\end{tabular}




\begin{tabular}{lcccc} 
Sodium $(\mathrm{g} / \mathrm{kg})$ & $9.17 \pm 4.67^{\mathrm{b}}$ & $8.59 \pm 1.59^{\mathrm{b}}$ & $10.30 \pm 1.83^{\mathrm{a}}$ & $13.82 \pm 5.22^{\mathrm{a}}$ \\
$\mathrm{pH}$ & $6.91 \pm 0.17^{\mathrm{a}}$ & $7.56 \pm 0.28^{\mathrm{a}}$ & $7.09 \pm 0.17^{\mathrm{a}}$ & $7.83 \pm 0.30^{\mathrm{a}}$ \\
Conductivity (dS/m) & $7.04 \pm 2.44^{\mathrm{b}}$ & $9.43 \pm 1.53^{\mathrm{b}}$ & $16.28 \pm 3.89^{\mathrm{a}}$ & $11.72 \pm 3.31^{\mathrm{a}}$ \\
Salinity & $13.7 \pm 9.6^{\mathrm{b}}$ & $16.8 \pm 7.7^{\mathrm{b}}$ & $21.1 \pm 20.5^{\mathrm{a}}$ & $21.7 \pm 21.0^{\mathrm{a}}$ \\
\hline
\end{tabular}

The percentages of sand majorly increases in the annual cycle in February and March, and September and January in the area of HD. The silt of the LD sites has three major increases in the annual cycle (January, March-April and August), and November, March and August in the HD sites. The clay showed a higher concentration in LD than HD sites. The percentage of clay showed an increase from February (dry season) to September (rainy season) in both sites.

The concentration of nitrogen was higher in LD than HD sites (Fig. 2). However, LD sites have a higher increase in October. The $\mathrm{P}$ concentration had a higher increase in February in the two sites LD and HD with $0.058 \mathrm{~g} \mathrm{~kg}^{-1}$ and $0.086 \mathrm{~g} \mathrm{~kg}^{-1}$, respectively, and a hydrologically dominated phase. LD sites had another increase in September and HD sites in April and July. A mean higher concentration of OM was found in LD sites (4.55 to $4.83 \%$ ) than in HD sites (3.20 to $2.79 \%$ ). The highest concentrations were found in November (LD) and March (HD) with 10\% and 12\%, respectively.

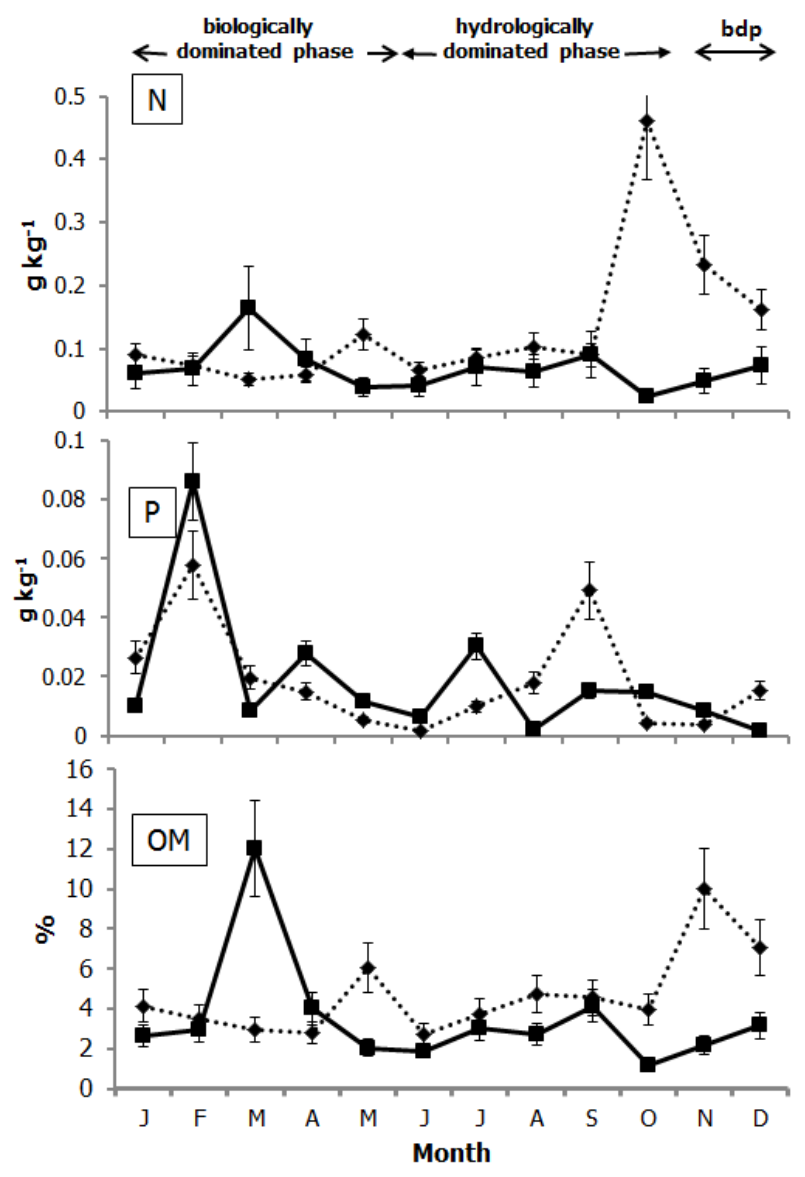

Figure 2. Variation annual of $N, P$ and $O M$ in $L D(\mathbf{m})$ and $H D(=)$ in soil collected from tidal basin Agua Brava Lagoon 
Increased K from April to November was found in LD (Fig. 3) sites. The K was found with a variation of 1.2 to $2.2 \mathrm{~g} \mathrm{~kg}^{-1}$ throughout the year in HD sites. Increased $\mathrm{Mg}$ from January $\left(0.16 \mathrm{~g} \mathrm{~kg}^{-1}\right)$ to August $\left(3.59 \mathrm{~g} \mathrm{~kg}^{-1}\right)$ was found in LD sites. The HD sites had a tendency to decrease from January $\left(3.65 \mathrm{~g} \mathrm{~kg}^{-1}\right)$ to December $\left(0.74 \mathrm{~g} \mathrm{~kg}^{-1}\right)$. The Ca concentration was higher in HD $\left(3.27 \mathrm{~g} \mathrm{~kg}^{-1}\right)$ than LD $\left(2.41 \mathrm{~g} \mathrm{~kg}^{-1}\right)$ sites. The HD present two increases in June $\left(5.0 \mathrm{~g} \mathrm{~kg}^{-1}\right)$ and November $\left(4.83 \mathrm{~g} \mathrm{~kg}^{-1}\right)$ and LD was only in May (5.01 $\left.\mathrm{g} \mathrm{kg}^{-1}\right)$. The $\mathrm{Na}$ was higher in HD (12.06 $\left.\mathrm{g} \mathrm{kg}^{-1}\right)$ and presented two increases in February $\left(44.41 \mathrm{~g} \mathrm{~kg}^{-1}\right)$ and May $\left(21.10 \mathrm{~g} \mathrm{~kg}^{-1}\right)$. HD sites was only in May $\left(42.51 \mathrm{~g} \mathrm{~kg}^{-1}\right)$.

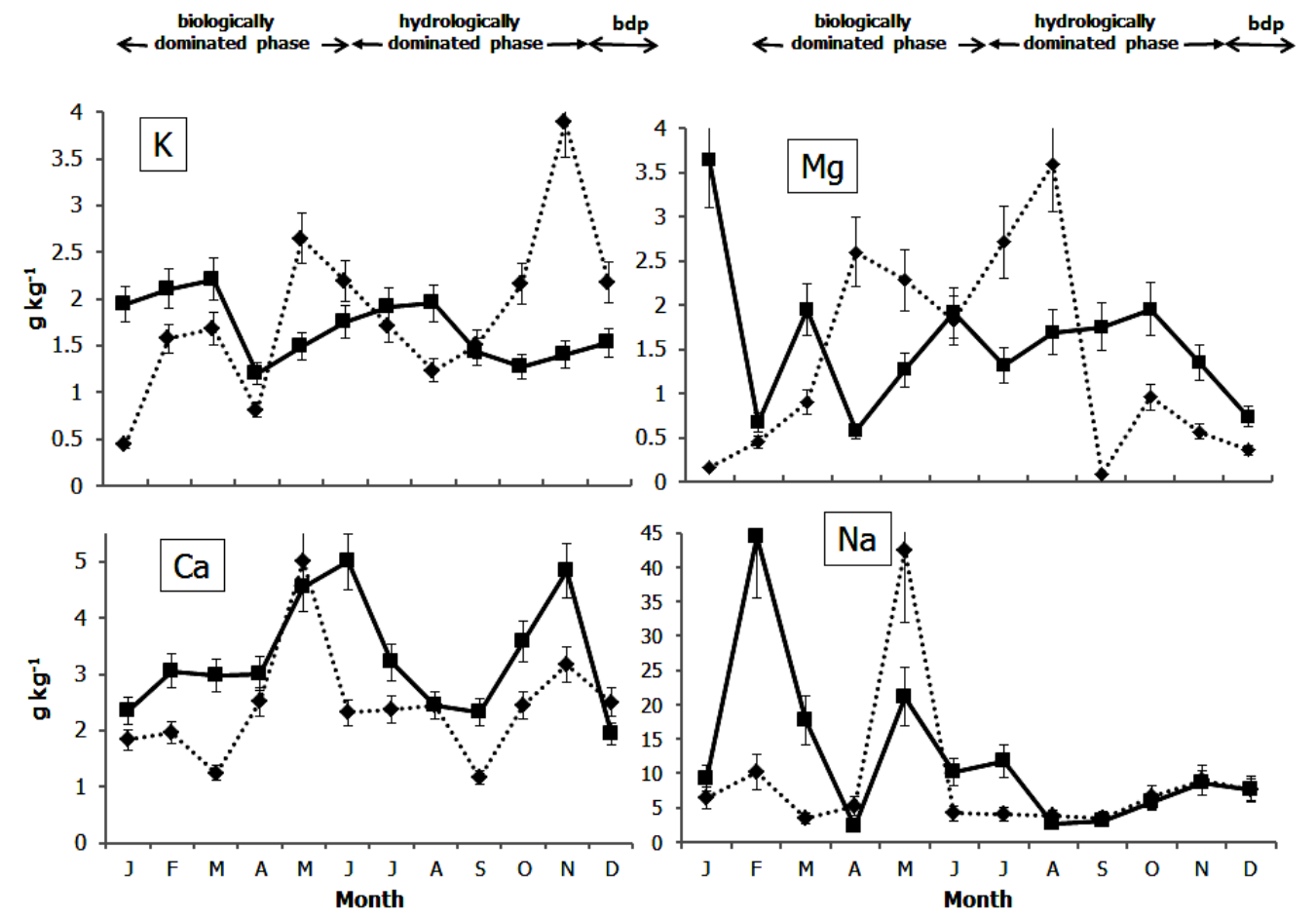

Figure 3. Variation annual of $K, M g, C a$ and $N a$ in $L D(, \cdot)$ and $H D(-)$ in soil collected from tidal basin Agua Brava Lagoon.

From the texture and soil chemical parameters, three principal components were extracted. The three components explained $61.2 \%$ of the variation. The relationship between soil parameters on the first and second PCA is shown in Fig. 4, while the parameters as grouped according to their loadings on the parameters components are presented in Table 2.

Table 2. Loadings from the PCA of texture and soil chemical parameters data for the first three components of the tropical tidal basin Agua Brava Lagoon. PCA = Principal Component Analysis; $* P<0.05 ;$ PC1, PC2, PC3 = Principal component 1, 2, 3 .

\begin{tabular}{lccc}
\hline Parameter & PC1 & PC2 & PC3 \\
\hline Sand & -0.137 & 0.105 & -0.099 \\
Silt & -0.248 & -0.154 & $-0.553^{*}$ \\
Clay & -0.048 & -0.079 & $0.622^{*}$
\end{tabular}




\begin{tabular}{lccc} 
Bulk Density & 0.354 & 0.264 & -0.057 \\
Organic matter & $0.432^{*}$ & -0.203 & -0.122 \\
Organic Carbon & $0.428^{*}$ & -0.202 & -0.126 \\
Nitrogen & $-0.423^{*}$ & 0.173 & 0.051 \\
Phosphorus & 0.007 & $-0.383^{*}$ & 0.040 \\
Potassium & -0.148 & $0.370^{*}$ & -0.013 \\
Calcium & -0.079 & $0.383^{*}$ & -0.042 \\
Magnesium & 0.165 & 0.295 & -0.280 \\
Sodium & 0.130 & $0.434^{*}$ & 0.073 \\
pH & 0.178 & 0.067 & 0.415 \\
Conductivity & 0.374 & 0.260 & -0.039 \\
\hline
\end{tabular}

The first component formed two groups with highest loadings of OM, OC and N, and the second group with $\mathrm{pH}, \mathrm{EC}$ and $\mathrm{D}$ (Fig. 4). The second component with the largest loadings were $\mathrm{P}, \mathrm{K}, \mathrm{Ca}$ and $\mathrm{Na}$ and the third component with the largest loadings were silt and clay. The first component was identified as the dynamics of OM-N and acidbasic relationship; the second component of the system with cation exchange capacity and the third component with soil texture dynamics mainly of clay.

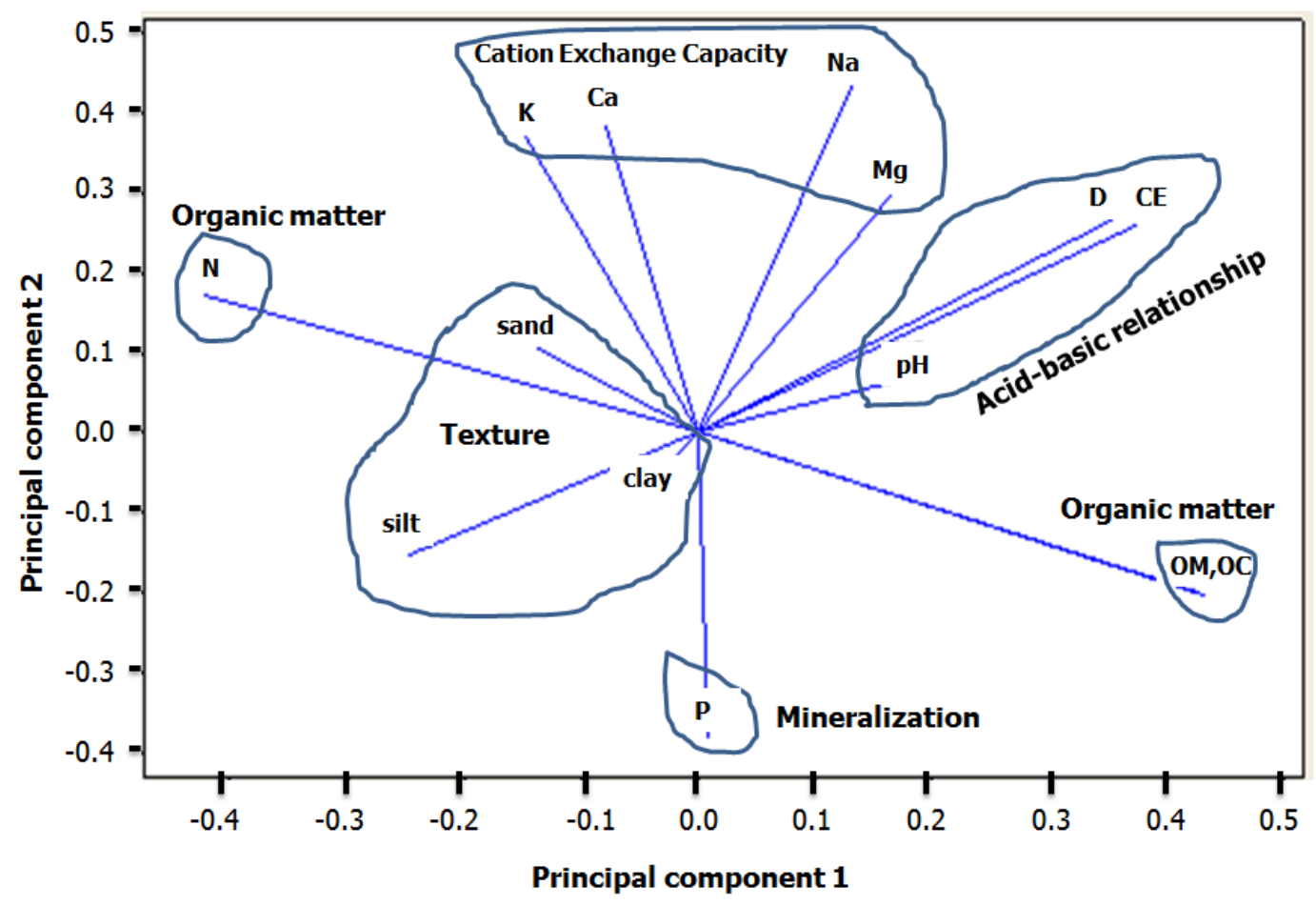

Figure 4. Principal component analysis (PCA) of texture and soil chemical parameters, on tidal basin Agua Brava Lagoon. 
The texture and soil chemical parameters analyzed by cluster analysis showed two groups (Fig. 5). The first was represented by LD sites, and the second by the HD sites, with greater similarity between LD sites.

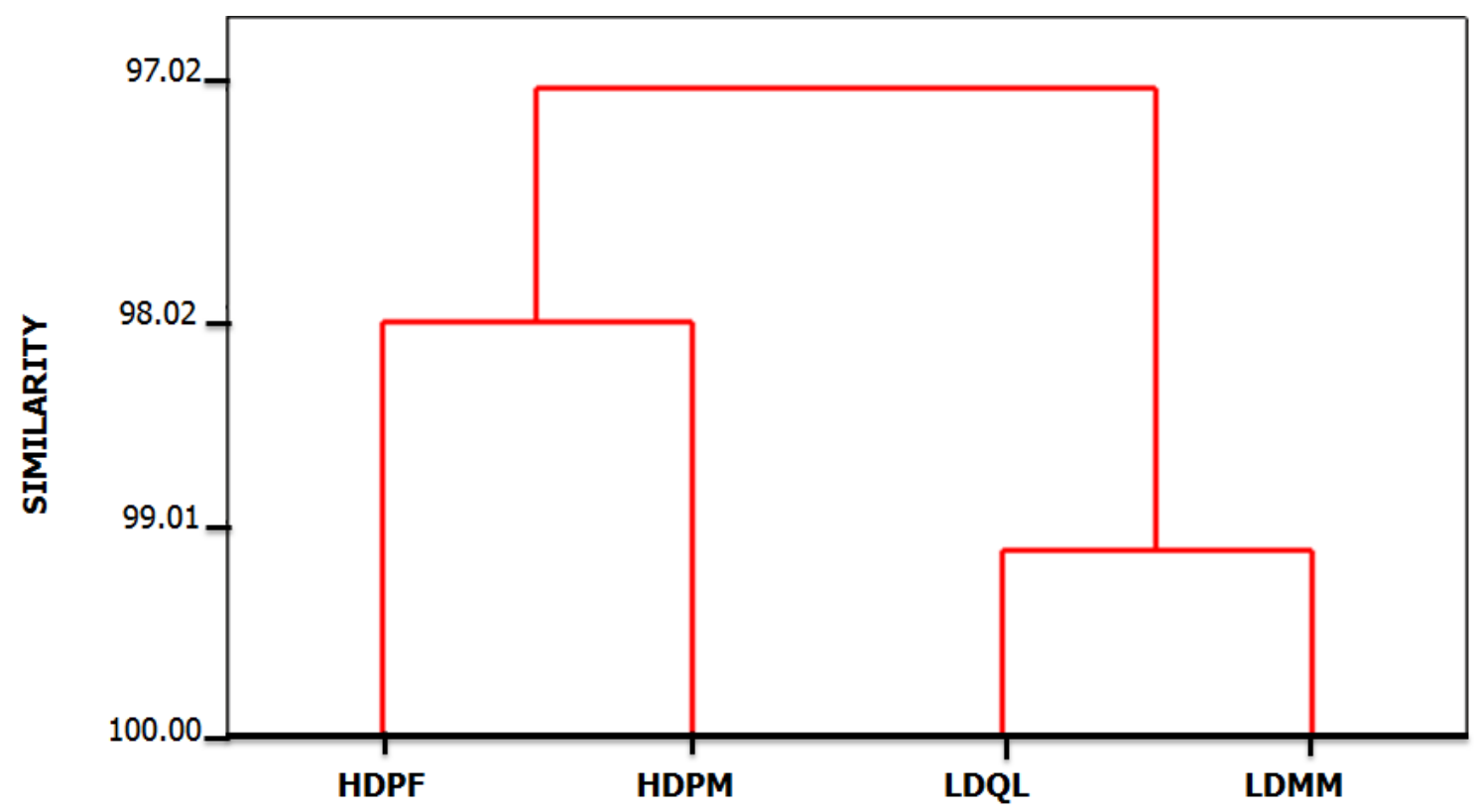

Figure 5. Dendrogram of texture and geochemistry soil collected from tidal basin Agua Brava Lagoon. LDQL, LDMM, HDPF and HDPM sampling stations.

\section{Discussion}

The mangroves of this system (Agua Brava Lagoon) showed degradation within the last few decades (Kovacks et al., 2005). The opening of the Cuautla channel modifies the conditions of the sedimentary process in the area with a tendency to be the softest (Kovacs, 2000). The gravel, sand, and clay fractions of mangrove sediments are related to sediment source (Madkour and Mohamed, 2008).

Geomorphological and geochemical processes and primary production control the formation, physical properties and chemical composition of soils in mangrove wetlands (Chen and Twilley, 1999). Physical and chemical characteristics of the soil constituted limitations of the structure of mangroves and productivity (Twilley, 1995). The soil texture revealed dominance of sands and silty clay in all the sites. An increase in the percentage of clay from January to November was found in both sites; it mainly increases in the hydrologically dominated phase (June to October). This was higher in LD sites. The particle size of mangrove soil in the coastal areas varies (Madkour et al., 2014) and the LD sites are characterized by softest sediment than the HD sites, this agrees with Satranegara (2004) who found that soils with less disturbance in mangrove areas have a more silty clay texture. There was a trend of clay soils in the LD and apparent density showed the lowest values in the HD which was also found by Lopez et al. (2011) in disturbance mangroves of Northwestern Venezuela. The LD sites are high in materials derived from upriver and terrestrial sources, such as clays, silt, OM and fine sediment with minor amounts of sand. Salt marshes soils typically contain more fine sands and clays from marine sources (Odum, 1988). 
The concentration of organic matter in soil varied seasonally in LD and HD sites. High concentrations occurred during biologically dominated phase. This is because the hydrological phase increases the bioturbation and the transportation of organic material from external sources as well as the removal and oxidation of $\mathrm{OM}$ within the sediments due to drying and cracking of the soil during dry season (Arenas and De la Lanza, 1981; Fagherazzi et al., 2013).

The OM tends to be accumulated in the highly reducing environment (Madkour and Mohamed, 2008). The type of hydrology influences the accumulation of OM, by weather and flood conditions, as well as species of the vegetation constituent (DiazMendoza et al., 2010). It has been found that mangroves that are located in basins under steady flood and OM can be exported in dissolved form. In contrast, if the mangroves are areas of constant water flow, OM is exported as suspended particles (Lopez-Portillo and Ezcurra, 2002). In this study LD and HD sites tend to behave like this. Although there are no significant differences in the particle size, a tendency to an increase of soil $\mathrm{OM}$ in the LD sites with decrease in particle size was found, which agrees with Madkour and Mohamed (2008). Studies on fluxes of OM have focused on the entire estuarine system, including fluxes from the ocean and nearby fluvial watersheds (Fagherazzi et al., 2013). However, it is important to determine the mechanisms controlling fluxes and the nature of $\mathrm{OM}$ within the tidal basin following the results of Arenas and De la Lanza (1981 and 1983) on soil OM biodegradability in a nearby coastal lagoon. The organic matter was increased during the dry season; this has been found in nearby lagoons (Arenas and De la Lanza, 1981). The OC content increases as particle size decreases. This is because the organic materials that are present essentially are combined with the mud fraction (Madkour et al., 2014).

The main reservoir for phosphorous and nitrogen was the soil (Silva, 2007), the results of $\mathrm{OC}$ and total $\mathrm{N}$ are related to the presence of $\mathrm{OM}$, greater vegetation cover; fallen leaves, roots, stems, flowers, among others (Ramírez-Fuentes and Trujillo-Tapia, 2015), provide more nutrients, and its concentration depends on the residence time of the $\mathrm{OM}$ in the soil and the type of plant residues. We found a higher concentration of $\mathrm{OC}$ and total $\mathrm{N}$ in LD sites.

The $\mathrm{P}$ in wetland sediments exists in both organic and inorganic forms. Most studies have shown that Organic $\mathrm{P}$ is strongly influenced by factors that include vegetation, moisture, temperature, and grain size (Xiao et al., 2012). Phosphorus cycle in tropical mangroves is multicyclic because of the periodic flooding of sediments with both fresh and saline waters (Salcedo and Medeiros, 1995).

Phosphorus retention and release in mangrove sediments depend on several factors including $\mathrm{pH}$, redox potential, tidal inundation, the nature of phosphorus compounds supplied to the sediment-water interface, sedimentation rate, bioturbation, diagenetic processes, etc. It was found that $\mathrm{P}$ is retained more in the HD mangrove forest soil with a higher concentration of $\mathrm{Ca}$ in this site; as the $\mathrm{P}$ when combined with $\mathrm{Ca}$ is the main mechanism of $\mathrm{P}$ retention (Joseph et al., 2011). The content of potential bioavailable $\mathrm{P}$ was only $10-20 \%$ of the total $\mathrm{P}$ in the soil which has also been found for the mangrove soil of the Hun River and Taizi River (Lin et al., 2009).

The $\mathrm{P}$ concentrations were lower in lagoon sites and flood plain soils than in mangrove forest, suggesting that the $\mathrm{P}$ could be limited which is in agreement with the findings of Tam and Wong (1998), and independent of the health status of mangroves.

The differences between $\mathrm{C} / \mathrm{P}$ of the $\mathrm{LD}$ and $\mathrm{HD}$ sites suggest different diagenetic processes as well as $\mathrm{OM}$ of a different nature. The variations in the concentration of $\mathrm{P}$ 
and OM among areas are due to the different sources of OC (aloctone source, detritus transported by the river, autochthone source, roots, invertebrates and others). Little relationship between $\mathrm{P}$ and $\mathrm{OM}$ was found. This is probably because most of $\mathrm{P}$ is detrital, which has been reported by Madkour et al. (2008). It was also found that in areas with mangrove, greatest influence was high concentration of $\mathrm{OM}$ and total $\mathrm{N}$ and $\mathrm{P}$ regardless of the health status of the mangroves, which shows the role of mangrove ecosystems as phosphorus traps (LDMM and HDPM) and exporters of carbon in LD sites (Arenas and De la Lanza, 1983). The $\mathrm{K}, \mathrm{Ca}$ and $\mathrm{Na}$ concentrations mean in sediment were highest during the dry season (biologically dominated phase) and lowest (hydrologically dominated phase) towards the end of the rainy season, similar to that found by Cohen et al. (1999) in the water column of a mangrove creek in Braganca, North Brazil. It was also found that $\mathrm{K}, \mathrm{Ca}$ and $\mathrm{Mg}$ concentrations showed a strong tidal rhythm due to the mixing of estuarine and mangrove waters and its variation depend on salinity and primary aquatic production (Manju et al., 2012).

A higher concentration of $\mathrm{Na}, \mathrm{EC}$ and salinity in the mangrove HD site was found, which is in agreement with those reported by Cardona and Botero (1998). A tendency to decrease the concentration of $\mathrm{Mg}$ in LD soil in December and January was found that the $\mathrm{pH}$ was 6.7 to 8.1. This is explained by absorption on suspension containing amorphous silica and the precipitation of Mghydroxysilicate resembling sepiolite. These two chemical processes occur at $\mathrm{pH} 9$ and above (Carmouze et al., 1998). It has been found that fringe mangroves were related to $\mathrm{Ca}$ concentration in the soil and increased dominance of Laguncularia racemosa and other non-mangrove tree species, while the riverine mangroves were associated with $\mathrm{Mg}$ concentration and the dominance of Rhizophora mangle (Polanía et al., 2015).

\section{Conclusion}

In general, soil texture tends to be softer in LD than in HD sites. There was a higher concentration of OM, OC, and $\mathrm{N}$ in LD sites. This was due to the degree of disturbance of the mangroves and physicochemical conditions of the soil and type of hydrological system flowing in tidal systems. The HD sites presented an environmental stress by high levels of $\mathrm{Ca}, \mathrm{Na}$, salinity and conductivity. The clay and $\mathrm{K}$ had a tendency to increase in the biologically dominated phase to the hydrologically dominated phase in LD and HD sites. The other parameters studied had a tendency to multicycle. Four processes that dominate the dynamics of the soil were identified to be mainly MO, OC and $\mathrm{N}$ relationship, and acid-base relationship. In addition, it was found that the texture and soil geochemistry of LD sites are more similar to themselves than those sites with HD. Finally we found that the soil conditions of LD and HD sites varies according to the level of disturbance in a mangrove and adjacent water body, thus demonstrating the importance of maintaining a healthy mangrove ecosystem.

\section{REFERENCES}

[1] Alongi, D. M. (2009): The Energetics of Mangrove Forests. - Springer, New York.

[2] Arenas, V., De la Lanza, G. (1981): The effect of dry and cracked sediment on the availability of phosphorus in a coastal lagoon. - Estuaries 4 (3): 206-212.

[3] Arenas, V., De la Lanza, G. (1983): Annual Phosphorus Budget of a Coastal Lagoon in the Northwest of Mexico. - Ecological Bulletins 35: 431-440. 
[4] Aschenbroich, A., Marchand, C., Molnar, N., Deborde, J., Hubas, C., Rybarczyk, H., Meziane, T. (2015): Spatio-temporal variations in the composition of organic matter in surface sediments of a mangrove receiving shrimp farm effluents (New Caledonia). Science of the Total Environment 512-513: 296-307.

[5] Barbier, E.B., Hacker, S.D., Kennedy, C., Koch, E.W., Stier, A.C., Silliman, B.R. (2011): The Value of Estuarine and Coastal Ecosystem Services. - Ecological Monographs 81 (2): 169-193.

[6] Beretta, A., Silbermann, A., Paladino, L., Torres, D., Bassahun, D., Musselli, R., GarcíaLamohte, A. (2014): Soil texture analyses using a hydrometer: modification of the Bouyoucos method. - Ciencia e Investigación Agraria 41 (2): 263-271.

[7] Cardona, P., Botero, L. (1998): Soil characteristics and vegetation structure in a heavily deteriorated mangrove forest in the Caribbean coast of Colombia. - Biotropica 30 (1): 2434.

[8] Carmouze, J.P., Galvao, S.G., Nishiara, L., Mesquita, H.S.L. (1998): Modelling chemical changes of tidal waters emerging from a mangrove forest at Cananeia, Brazil. Mangroves Salt Marshes 2: 43-49.

[9] Chen, G.C., Ye, Y. (2010): Changes in properties of mangrove sediment due to foraging on Kandelia obovata leaves by crabs Parasesarmea plicatum (Grapsidae: Sesarminae). Marine Ecology Progress Series 419: 137-145.

[10] Chen, R., Twilley, R.R. (1999): A simulation model of organic matter and nutrient accumulation in mangrove wetland soils. - Biogeochemistry 44: 93-118.

[11] Cohen, M.C.L., Lara, R.J., Ramos, J.F.F., Dittmar, T. (1999): Factors influencing the variability of $\mathrm{Mg}, \mathrm{Ca}$ and $\mathrm{K}$ in waters of a mangrove creek in Braganca, North Brazil. Mangroves Salt Marshes 3: 9-15.

[12] Díaz-Mendoza, C., Castro-Angulo, I., Manjarrez-Paba, G. (2010): Manglares de Cartagena de Indias: Patrimonio biológico y fuente de biodiversidad. Fundación Universitaria Tecnológico Comfenalco. Cartagena, Colombia, p. 72.

[13] Fagherazzi, S., Wiberg, P.L., Temmerman, S., Struyf, E., Zhao, Y., Raymond, P.A. (2013): Fluxes of water, sediments, and biogeochemical compounds in salt marshes. Ecological Processes 2 (3): 1-16.

[14] Flores-Verdugo, F., Amezcua, F., Kovacs, J.M., Serrano, D., Blanco-Correa, M. (2014): Changes in the Hydrological Regime of Coastal Lagoons Affect Mangroves and Small Scale Fisheries: The Case of the Mangrove-Estuarine Complex of Marismas Nacionales (Pacific Coast of Mexico). - In: Amezcua, F., Bellgraph, B. (eds.) Fisheries Management of Mexican and Central American Estuaries. pp. 81-91.

[15] Hendershot, W.H., Lalande, H., Duquette, M. (2008): Ion exchange and exchangeable cations. - In: Carter, M.R., Gregorich, E.G. (eds.) Soil sampling methods of analysis, 2nd ed. Canadian Society of Soil Science. pp. 197-206.

[16] Hernández-Guzmán, R., Ruiz-Luna, A., Berlanga-Robles, C. (2008): Assessment of runoff response to landscape changes in the San Pedro subbasin (Nayarit, Mexico) using remote sensing data and GIS. - Journal of Environmental Science and Health, Part A 43 (12): 1471-1482.

[17] Joseph, M.M., Kumar, C.S.R., Renjith, K.R., Kumar, T.R.G., Chandramohanakumar, N. (2011): Phosphorus fractions in the surface sediments of three mangrove systems of southwest coast of India. - Environmental Earth Sciences 62: 1209-1218.

[18] Kovacs J.M. (2000): Perceptions of environmental change in a tropical coastal wetland. Land Degradation \& Development 11: 209-220.

[19] Kovacs, J.M., Wang, J., Flores-Verdugo, F. (2005): Mapping mangrove leaf area index at the species level using IKONOS and LAI-2000 sensors for the Agua Brava Lagoon, Mexican Pacific. - Estuarine, Coastal and Shelf Science 62: 377-384.

[20] Kovacs, J.M., King, J.M.L., Flores de Santiago, F., Flores-Verdugo, F. (2009): Evaluating the condition of a mangrove forest of the Mexican Pacific based on an 
estimated leaf area index mapping approach. - Environmental Monitoring and Assessment 157: 137-149.

[21] Leopold, A., Marchand, C., Deborde, J., Allenbach, M. (2015): Temporal variability of $\mathrm{CO} 2$ fluxes at the sediment-air interface in mangroves (New Caledonia). - Science of the Total Environment 502: 617-626.

[22] Lin, C., Wang, Z., He, M., Li, Y., Liu, R., Yang, Z. (2009): Phosphorus sorption and fraction characteristics in the upper, middle and low reach sediments of the Daliao river systems, China. - Journal of Hazardous Materials 170: 278-285.

[23] López, B., Barreto, M.B., Conde, J.E. (2011): Caracterización de los manglares de zonas semiáridas en el noroccidente de Venezuela. - Interciencia 36 (12): 888-893.

[24] López-Portillo, J., Ezcurra, E. (2002): Los manglares de México: una revisión. - Madera Bosques 8: 27-51.

[25] Lyu, X., Yu, J., Zhou, M., Ma, B., Wang, G., Zhan, C., Han, G., Guan, B., Wu, H., Li, Y., Wang, D. (2015): Changes of Soil Particle Size Distribution in Tidal Flats in the Yellow River Delta. - PLoS ONE 10 (3): e0121368. doi:10.1371/journal. pone.0121368

[26] Mackey, A.P., Hodgkinson, M.C. (1995): Concentration and spatial distribution of trace metals in mangrove sediments from the Brisbane River, Australia. - Environmental Pollution 90: 181-186.

[27] Madkour, H.A., Mohamed, A.W. (2008): Nature and geochemistry of surface marine sediments of mangrove environment along the Egyptian Red Sea Coast. - Environmental Geology 54: 257-267.

[28] Madkour, H.A., Mansour, A.M., Ahmed, A.E.H.N., El-Taher, A. (2014): Environmental texture and geochemistry of the sediments of a subtropical mangrove ecosystem and surrounding areas, Red Sea Coast, Egypt. - Arabian Journal of Geosciences 7: 34273440.

[29] Manju, M.N., Resmi, P., Kumar, T.R.G., Kumar, R., Rahul, C.S., Joseph, M.M.R., Chandramohanakumar, N. (2012): Assessment of water quality parameters in mangrove ecosystems along Kerala coast: a statistical approach. - International Journal of Environmental Research 6 (4): 893-902.

[30] Marchand, C., Baltzer, F., Lallier-Vergès, E., Albéric, P. (2004): Pore-water chemistry in mangrove sediments: Relationship with species composition and developmental stages (French Guiana). - Marine Geology 208: 361-381.

[31] Molnar, N., Welsh, D.T., Marchand, C., Deborde, J., Meziane, T. (2013): Impacts of shrimp farm effluent on water quality, benthic metabolism and $\mathrm{N}$-dynamics in a mangrove forest (New Caledonia). - Estuarine, Coastal and Shelf Science 117: 12-21.

[32] Nerot, C., Meziane, T., Provost-Govrich, A., Rybarczyk, H., Lee, S.Y. (2009): Role of grapsid crabs, Parasesarma erythrodactyla, in entry of mangrove leaves into an estuarine food web: a mesocosm study. - Marine Biology 156: 2343-2352.

[33] Odum, W.E. (1988): Comparative ecology of tidal freshwater and salt marshes. - Annual Review of Ecology, Evolution, and Systematics 19: 147-176.

[34] Osland, M.J., Enwright, N., Day, R.H., Doyle, T.W. (2013): Winter climate change and coastal wetland foundation species: salt marshes vs. mangrove forests in the southeastern United States. - Global Change Biology 19: 1482-1494.

[35] Otero, X.L., Ferreira, T.O., Huerta-Díaz, M.A., Partiti, C.S.M., Souza, JrV., VidalTorrado, P., Macías, F. (2009): Geochemistry of iron and manganese in soils and sediments of a mangrove system, Island of Pai Matos (Cananeia - SP, Brazil). Geoderma 148: 318-335.

[36] Parker, J.G. (1983): A Comparison of Methods used for the Measurement of Organic Matter in Marine Sediment. - Chemistry and Ecology 1(3): 201-209.

[37] Polanía, J., Urrego, L.E., Agudelo, C.M. (2015): Recent advances in understanding Colombian mangroves. - Acta Oecologica 63: 82-90.

[38] Pool, D.J., Snedaker, S.C., Lugo, A. (1977): Structure of mangrove forests in Florida, Puerto Rico, Mexico and Costa Rica. - Biotropica 9: 195-212. 
[39] Ramírez-Fuentes, E., Trujillo-Tapia, M.N. (2015): Nitrificación y mineralización del N en un suelo perturbado de manglar en la costa del Pacífico Sur, Oaxaca. - ReIbCi 2 (3): 65-75.

[40] Ramos e Silva, C.A., Oliveira, S.R., Rego, R.D.P., Mozeto, A.A. (2007): Dynamics of phosphorus and nitrogen through litter fall and decomposition in a tropical mangrove forest. - Marine Environmental Research 64 (4): 524-34.

[41] Ranjan, R.K., Routh, J., Ramanathan, A.L., Klump, J.V. (2011): Elemental and stable isotope records of organic matter input and its fate in the Pichavaram mangrove-estuarine sediments (Tamil Nadu, India). - Marine Chemistry 126: 163-172.

[42] Salcedo, I.H., Medeiros, C. (1995): Phosphorus Transfer from Tropical Terrestrial To Aquatic Systems - Mangroves. In: Tiessen (Ed.) Phosphorus in the Global Environment. pp. 347-362.

[43] Satranegara, M.H. (2004): The impact of forest use on the intertidal crab community in managed mangroves of Cilacap, Central Java, Indonesia. - Cuvillier Verlag, Göttingen, Germany, $97 \mathrm{p}$.

[44] Silva, W.G., Metzger, J.P., Simões, S., Simonetti, C. (2007): Relief influence on the spatial distribution of the Atlantic Forest cover on the Ibiúna Plateau, SP. Brazil. - Journal of Biology 67: 631-637.

[45] Sun, Z., Mou, X., Tong, C., Wang, C., Xie, Z., Song, H., Sun, W., Lv, Y. (2015): Spatial variations and bioaccumulation of heavymetals in intertidal zone of the Yellow River estuary, China. - Catena 126: 43-52.

[46] Tam, N.F., Wong, Y.S. (1998): Variations of soil nutrient and organic matter content in a subtropical mangrove ecosystem. - Water, Air, \& Soil Pollution 103: 245-261.

[47] Tam, N.F.Y., Wong, Y.S. (2000): Spatial variation of heavy metals in surface sediments of Hong Kong mangrove swamps. - Environmental Pollution 110: 195-205.

[48] Twilley, R.R. (1995): Properties of mangrove ecosystems related to the energy signature of coastal environments. - In: Hall, C. (ed) Maximum Power. University of Colorado Press, Boulder, Colorado, pp. 43-62

[49] Vertacnik, A., Prohic, E., Kozar, S., Juracic, M. (1995): Behaviour of some trace elements in alluvial sediments, Zagerb water-well field area, Croatia. - Water Research 29: 237-246.

[50] Xiao, R., Bai, J., Gao, H., Huang, L., Deng, W. (2012): Spatial distribution of phosphorus in marsh soils of a typical land/inland water ecotone along a hydrological gradient. Catena 98: 96-103.

[51] Zhang, C., Kovacs, J.M., Liu, Y., Flores-Verdugo, F., Flores-de-Santiago, F. (2014): Separating mangrove species and conditions using laboratory hyperspectral data: a case study of a degraded mangrove forest of the Mexican pacific. - Remote Sensing 6: 1167311688 . 